\title{
PENERAPAN MODEL VALUE CLARIFICATION TECHNIQUE (VCT) BERBANTUAN FILM DOKUMENTER DALAM MENANAMKAN NILAI NASIONALISME DAN MENINGKATKAN HASIL BELAJAR PADA SISWA SEKOLAH DASAR
}

\author{
Sutaryanto \\ Profi PGSD FIP IKIP PGRI MADIUN \\ zut4ryanto@gmail.com
}

\begin{abstract}
This research is conducted to integrate the model, review the process and results of the model application, and analyze the differences between the application of students learning outcomes using learning model VCT assisted the documentary film with conventional learning in social studies. This research is a kind of mixed methods with experimental design. The data is derived using observation, documentation, attitude scale, and tests. The application of the Value Clarification Technique (VCT) models assisted the documentary film is very effective. It can be seen from the teacher's observation, student attitudes, analysis of students' worksheet, students response with very good criteria, and the results show the attitude scale test of the Value Clarification Technique (VCT) models assisted the documentary film effectivein instilling the value of nationalism. There is a difference in student learning outcomes between experimental and control classes. Student learning outcomes experimental class are higher than the control class.
\end{abstract}

Keywords: The Value Clarification Technique (VCT) models, Documentary Film, Nationalism Values, Student learning outcomes.

\begin{abstract}
Abstrak
Penelitian ini dilakukan untuk memadukan model, mengkaji proses dan hasil penerapan model dan menganalisis perbedaan hasil belajar siswa antara penerapan model pembelajaran VCT berbantuan film dokumenter dengan pembelajaran konvensional pada mata pelajaran IPS. Penelitian ini adalah penelitian jenis metode campuran dengan desain eksperimen. Data diambil dengan observasi, dokumentasi, skala sikap (likert), dan tes. Penerapan model Value Clarification Technique (VCT) berbantuan film dokumenter sangat efektif. Hal ini dapat dilihat dari hasil observasi guru, sikap siswa, analisis Lembar Kerja Siswa, respon siswa dengan kriteria sangat baik, dan hasil tes skala sikap menunjukkan model Value Clarification Technique (VCT) berbantuan film dokumenter efektif dalam menanamkan nilai nasionalisme. Terdapat perbedaan hasil belajar siswa antara kelas eksperimen dan kontrol. Hasil belajar siswa kelas eksperimen lebih tinggi dari pada kelas kontrol.
\end{abstract}

Kata Kunci: $\quad$ Model Value Clarification Technique, Film Dokumenter, Nilai Nasionalisme, Hasil belajar siswa. 


\section{A. Pendahuluan}

Pada dasarnya pendidikan di Indonesia merupakan suatu usaha sadar dan terencana untuk mewujudkan suasana belajar dan proses pembelajaran supaya peserta didik secara aktif mampu mengembangkan potensi dirinya untuk memiliki kekuatan spiritual keagamaan, pengendalian diri, kepribadian, kecerdasan, akhlak mulia, serta keterampilan yang diperlukan dirinya, masyarakat, bangsa dan negara (UU Nomor 20 Tahun 2003). Selain itu fungsi pendidikan nasional adalah untuk mengembangkan kemampuan dan membentuk karakter serta peradaban bangsa yang bermartabat dalam rangka mencerdaskan kehidupan bangsa (Depdiknas 2003: 8). Dari semua penjelasan tersebut sangat jelas bahwa sesungguhnya pendidikan diharapkan dapat mengembangkan potensi diri peserta didik baik dalam mengembangkan kemampuan dan juga dalam membentuk karakter peserta didik.

Perkembangan zaman yang tidak dapat dihindari sekarang ini adalah era globalisasi. Dampak dari globalisasi selain memberikan harapan juga memunculkan berbagai masalah. Dampak yang paling menakutkan salah satunya adalah kecenderungan masyarakat kehilangan jati dirinya sebagai manusia indonesia akibat dari pergaulan global. Bersamaan dengan hal tersebut rasa nasionalisme juga akan terkikis. Menjawab tantangan sekaligus peluang kehidupan global di atas, diperlukan paradigma baru dalam pendidikan. Untuk melakukan reformulasi pendidikan adalah dengan menguatkan pendidikan karakter. Pendidikan karakter dapat dilaksanakan dengan penanaman nilai-nilai karakter dalam proses pembelajaran di kelas.

Mata pelajaran IPS merupakan salah satu mata pelajaran yang memiliki muatan karakter diantaranya yaitu dalam menanamkan nilai karakter kebangsaan (nasionalis). Penanaman nilai nasionalisme pada mata pelajaran IPS dapat dilakukan dengan meneladani kisah para tokoh perjuangan bangsa Indonesia. Suprayogi dkk, (2011: 8) menyatakan bahwa pada dasarnya Ilmu Pengetahuan Sosial (IPS) bertujuan untuk mempersiapkan peserta didik sebagai warga negara yang menguasai pengetahuan (knowledge), keterampilan (skills), sikap dan nilai (attitude and value) yang dapat digunakan sebagai kemampuan untuk memecahkan masalah pribadi atau sosial, serta kemampuan mengambil keputusan dan berpartisipasi dalam berbagai kegiatan kemasyarakatan agar menjadi warga negara yang baik. Mata pelajaran IPS merupakan suatu program keseluruhan pada pokoknya mempersoalkan manusia dalam lingkungan dalam lingkungan fisik maupun dalam lingkungan sosial. 
Oleh sebab itu, mata pelajaran IPS sangat dimungkinkan untuk menanamkan nilai-nilai karakter seperti nilai nasionalisme kepada peserta didik agar tumbuh dan berkembang menjadi warga negara yang baik dengan mengetahui hak dan kewajiban sebagai warga negara Indonesia. Penerapkan model Value Clarification Technique (VCT) dengan berbantuan film dokumenter diharapkan akan lebih mempermudah siswa dalam menentukan nilai-nilai nasionalisme serta dapat memberikan pengaruh yang positif terhadap hasil belajar pada siswa sekolah dasar.

\section{B. Pembahasan}

Penelitian ini adalah jenis metode campuran. Pertama menggunakan analisis deskriptif dan kedua menggunakan analisis kuantitatif. Penelitian ini menggunakan desain penelitian kuasi eksperimen dengan pretest dan postest dengan tipe "non equivalent control group design". Penenelitian ini menggunakan kelas eksperimen dan kelas kontrol. Kelas eksperimen diberi perlakuan (treatment) dan kelas kontrol tanpa perlakuan (treatment). Penelitian didahului dengan analisis deskriptif kualitatif kemudian menggunakan analisis kuantitatif.

Data diambil dengan observasi, dokumentasi, skala sikap (likert), dan tes. Uji coba instrumen yang digunakan yaitu uji validitas, uji reliabilitas dengan menggunakan $\mathrm{K}$ R 20, uji taraf kesukaran soal, dan uji daya beda soal. Analisis data menggunakan uji prasyarat dan uji hipotesis dan menggunakan uji NGain. Uji prasyarat yang digunakan adalah uji normalitas dan uji homogenitas.

Untuk menguji normalitas menggunakan uji KolmogorovSmirnov, uji homogenitas menggunakan uji Levene's test dan uji hipotesis menggunakan uji t-test dan N-Gain.

\section{Model Pembelajarn Value Clarification technique(VCT) berbantuan film dokumenter}

Djahiri (1985) menjelaskan bahwa Value Clarification technique(VCT), merupakan sebuah cara bagaimana menanamkan dan menggali atau mengungkapkan nilainilai tertentu dari diri peserta didik. Menurut Djahiri (1985) model pembelajaran VCT meliputi; metode percontohan, metode analisis nilai, metode daftar/matriks, metode kartu keyakinan, metode wawancara, metode yurisprudensi dan metode inkuiri nilai.

Peneliti menggunakan model VCT dengan metode percontohan sebagai langkah dalam kegiatan pembelajaran nilai nasionalisme kepada siswa sekolah dasar. Film dokumenter digunakan sebagai contoh stimulus yang diberikan dalam proses pembelajaran nilai. Film tersebut terdapat dilema yang dialami oleh para tokoh pejuang di 
Indonesia dalam mempertahankan kemerdekaan. Berdasarkan tahapan model VCT siswa akan dihadapkan pada dilema seperti yang dialami oleh para tokoh pejuang sesuai dengan film yang telah disaksikan siswa. Siswa akan menentukan keputusan, alasan, klarifikasi nilai nasionalisme dan memberikan contoh.

Skema Model VCT berbantuan film dokumenter seperti di bawah ini:

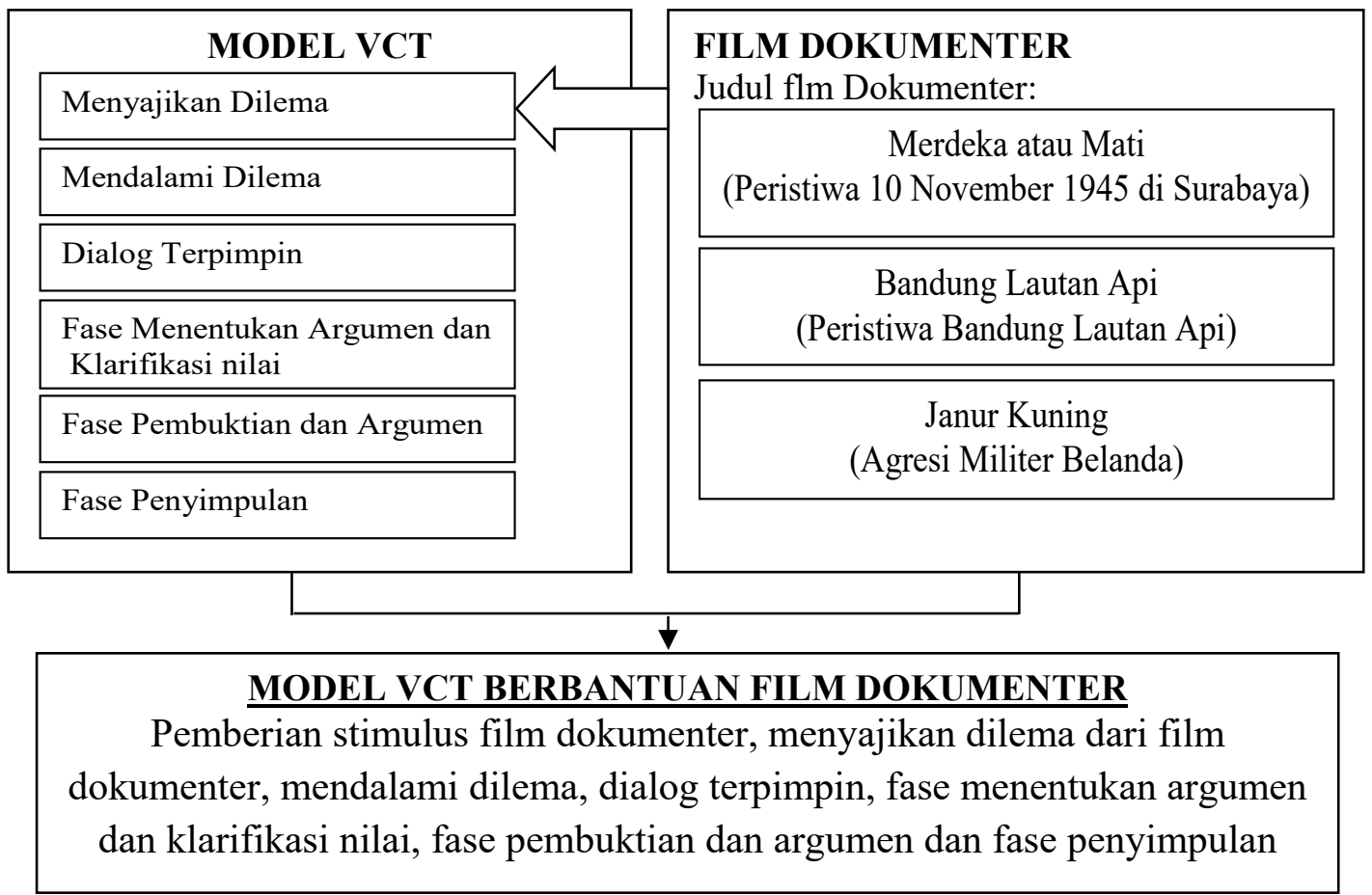

Gambar 1Model VCT Berbantuan Film Dokumenter

Proses penerapan model VCT (Value Clarification Technique) berbantuan film dokumenter sebagai berikut: a) kegiatan awal yang secara garis besar adalah salam, doa, absensi kehadiran, apersepsi dan pembentukan kelompok, b) kegiatan inti yang terdiri dari

(1) Ekplorasi (penanaman nilai nasionalisme kepada siswa yang diterapkan dalam penelitian ini dilakukan melaluipemberia stimulus yang berupa film dokumenter kepada siswa, dari film tersebut guru memberikan pernyataan kepada siswa yang bersifat dilematis).

(2) Elaborasi(dalam kegiatan ini guru memberikan kesempatan kepada siswa untuk diskusi kelompok dari pernyataan dilematis yang skenarionya terdapat di dalam Lembar Kerja Siswa (LKS). Kemudian siswa diminta untuk menentukan tindakan dari pernyataan tersebut. Siswa diberikan kesempatan untuk menentukan 
tindakan yang tepat berdasarkan apa yang mereka anggap benar dengan memberikan alasan. Berdasarkan keputusan dan alasan inilah siswa akan menemukan nilai nasionalisme yang sesuai dengan apa yang mereka lihat melalui tayangan film dokumenter. Siswa dalam menentukan nilai dibantu dari beberapa alternatif nilai, karena untuk membatasi agar nilai-nilai yang diharapkan dapat tercapai. Nilai yang diharapkan adalah nilai cinta tanah air, semangat kebangsaan, rela berkorban, tanggungjawab, pantang menyerah dan kepedulian.)

(3) Konfirmasi (pada fase penyimpulan guru menjelaskan cara bagaimana mengimplementasikan nilai-nilai nasionalisme dalam kehidupan sehari-hari. Hal ini merupakan langkah dalam penanaman nilai nasionalisme yang dapat diterapkan siswa dalam kehidupan sehari-hari, sehingga diharapkan ada output dalam penanaman nilai nasionalisme kepada siswa). c) kegiatan penutup (dalam kegiatan penutup guru dengan siswa membuat kesimpulan dan melakukan evaluasi pembelajaran dan pada akhir kegiatan pemlajaran guru memberi tugas kepada siswa dengan meminta siswa untuk membaca di rumah bahan ajar yang telah disediakan oleh guru)

Pelaksanaan tahapan-tahapan model Value Clarifikation Technique (VCT) berbantuan film dokumenter yang dilakukan oleh guru dianalisis dengan menggunakan data hasil observasi yang dilakukan oleh observer dengan menggukanan format observasi keterlaksanaan model Value Clarifikation Technique (VCT) berbantuan film documenter

2. Observasi Pelaksanaan Guru Dalam Kegiatan Belajar Mengajar

Kemudian data yang diperoleh dianalisis dengan menghitung presentase keterlaksanaan. Hasil yang diperoleh pada pertemuan ke-1, ke-2, dan ke-3 adalah seperti pada Tabel 1 berikut.

Tabel 1 Observasi Pelaksanaan Guru Dalam KBM di SDN Duyungan 1 dan di SDN Sidoharjo 2

\begin{tabular}{ccccc}
\hline \multirow{2}{*}{ Pertemuan Ke- } & \multicolumn{2}{c}{$\begin{array}{c}\text { Pelaksanaan di SDN } \\
\text { Duyungan 1 }\end{array}$} & \multicolumn{2}{c}{$\begin{array}{c}\text { Pelaksanaan di SDN } \\
\text { Sidoharjo 2 }\end{array}$} \\
\cline { 2 - 5 } & Ya (\%) & Tidak (\%) & Ya (\%) & Tidak (\%) \\
\hline 1 & 86 & 14 & 100 & 0 \\
2 & 100 & 0 & 100 & 0 \\
3 & 100 & 0 & 100 & 0 \\
Rata-rata & 95 & 5 & 100 & 0 \\
\hline
\end{tabular}


Berdasarkan hasil observasi guru di SDN Duyungan 1 keterlaksanaan guru rata-rata mencapai $95 \%$ berhasil dan 5\% tidak terlaksana. Tahapan yang tidak dilaksanaakn guru yaitu belum menyampaikan tujuan pembelajaran, meminta anak untuk menyimak bahan ajar, dan belum memberikan kesempatan anak untuk berpikir. Sedangkan Berdasarkan hasil observasi guru di SDN Sidoharjo 2 rata-rata telah melaksanaakan $100 \%$ tahapan kegiatan belajar mengajar, akan tetapi guru juga ada kekurangan yaitu pada pertemuan 1 dalam pelaksanaan kegiatan belajar mengajar guru melebihi batas waktu yang ditentukan, yaitu pada kegiatan tanya jawab dan penjelasan materi. Secara keseluruhan pelaksanaan kegiatan belajar mengajar baik di SDN Duyungan 1 dan di SDN
Sidoharjo 2 dapat dikatakan terlaksana dengan sangat baik. Persentase terlaksananya kegiatan belajar mengajar dari keduanya mencapai 97\%, sehingga dapat dikatakan guru sangat baik dalam melaksanakan tahapan-tahapan kegiatan belajar mengajar dengan menggunakan model VCT berbantuan film dokumenter.

\section{Penilaian sikap nasionalisme}

Penilaian sikap nasionalisme ini dilakukan untuk mengetahui perilaku yang nampak pada saat kegiatan belajar mengajar yang mencerminkan sikap nasionalisme (cinta tanah air, semangat kebangsaan, rela berkorban, tanggung jawab, pantang menyerah dan kepedulian). Secara keseluruhan rata-rata sikap siswa adalah seperti pada Tabel 2 berikut.

Tabel 2 Rata-rata sikap siswa

\begin{tabular}{ccc}
\hline Data & SDN Duyungan 1 & SDN Sidoharjo 2 \\
\hline Jumlah siswa & 30 & 35 \\
Rata-rata & 39,09 & 39,71 \\
Persentase & $81 \%$ & $83 \%$ \\
\hline Rata-rata Persentase & & $82 \%$ \\
\hline
\end{tabular}

Sikap siswa di SDN Duyungan 1 mendapatkan rata-rata sebesar $81 \%$. Sedangkan di SDN Sidoharjo 2 mendapatkan rata-rata sebesar $83 \%$. Persentase sikap siswa dari keduanya mencapai rata-rata $82 \%$. Hasil tersebut menunjukkan bahwa sikap nasionalisme siswa dalam kegiatan belajar mengajar secara keseluruhan termasuk dalam kriteria sangat baik. Jika dilihat secara keseluruhan selama proses kegiatan belajar mengajar di kelas, siswa sangat antusias ketika menyaksikan tayangan film dokumenter perjuangan bangsa Indonesia dalam mempertahankan kemerdekaan. Selain itu, siswa juga berpartisipasi aktif dalam kegiatan 
tanya jawab dan presentasi hasil kelompok.

Berdasarkan tabel di atas diketahui bahwa pada pertemuan pertama siswa dapat menyelesaikan ketercapaian indikator-indikator penanaman nilai nasionalisme dalam Lembar Kerja Siswa (LKS) sebesar $69 \%$. Hal ini dikarenakan siswa belum menyesuaikan dengan pelaksanaan model VCT berbantuan film. Hasil analisis LKS pertemuan kedua siswa mencapai rata-rata $84 \%$ dan pertemuan ketiga mencapai ratarata $94 \%$.

\section{Analisis Lembar Kerja Siswa}

Secara keseluruhan rata-rata dari pertemuan pertama sampai pertemuan ke tiga telah mencapai $82 \%$, hal ini dapat dikatakan bahwa siswa SDN Duyungan 1 dapat menyelesaikan ketercapaian indikator-indikator penanaman nilai nasionalisme dalam Lembar Kerja Siswa (LKS) dengan sangat baik. Siswa dapat menentukan keputusan, alasan dan menentukan nilai nasionalisme serta contohnya dengan sangat baik.

Hasil analisis Lembar Kerja Siswa (LKS) di SDN Duyungan 1 adalah seperti pada Tabel 3 berikut.

Tabel 3 Analisis LKS di SDN Duyungan 1

\begin{tabular}{cccc}
\hline \multirow{2}{*}{ Kelompok } & \multicolumn{3}{c}{ Pertemuan } \\
\cline { 2 - 4 } & Pertama & Kedua & Ketiga \\
\hline Total & 22 & 27 & 30 \\
Rata-rata & 2,75 & 3,375 & 3,75 \\
Persentase & $69 \%$ & $84 \%$ & $94 \%$ \\
\hline Rata-rata & \multicolumn{3}{|c}{$82 \%$} \\
persentase & \multicolumn{3}{|}{} \\
\hline
\end{tabular}

Hasil analisis Lembar Kerja Siswa (LKS) di SDN Sidoharjo 2 adalah seperti pada tabel 4 berikut.

Tabel 4 Analisis LKS di SDN Sidoharjo 2

\begin{tabular}{cccc}
\hline \multirow{2}{*}{ Kelompok } & \multicolumn{3}{c}{ Pertemuan } \\
\cline { 2 - 4 } & Pertama & Kedua & Ketiga \\
\hline Total & 27 & 35 & 33 \\
Rata-rata & 3 & 3,89 & 3,67 \\
Persentase & $75 \%$ & $97 \%$ & $92 \%$ \\
\hline Rata-rata & \multicolumn{3}{|c}{$88 \%$} \\
persentase & & \\
\hline
\end{tabular}

Berdasarkan tabel tersebut dapat dilihat persentase ketercapaian indikator-indikator penanaman nilai nasionalisme dalam Lembar Kerja Siswa (LKS). Hasil analisis LKS pertemuan pertama siswa mencapai $75 \%$, pertemuan kedua mencapai rata-rata $97 \%$ dan pada pertemuan ketiga mencapai 92\%, jika dilihat dari kriteria penilaian disetiap pertemuan mencapai rata-rata $\geq 75$ dengan kriterian sangat baik. Hasil dari pertemuan pertama, ke-dua dan ke-tiga rata-rata mencapai $88 \%$. Berdasarkan perolehan persentase ketercapaian indikator-indikator penanaman nilai nasionalisme dalam Lembar Kerja Siswa (LKS) tersebut, maka rata-rata siswa SDN Sidoharjo 2 dapat dikatakan sangat baik.

Bardasarkan analisis ketercapaian indikator-indikator penanaman nilai nasionalisme dalam Lembar Kerja Siswa (LKS), persentase hasil kerja kelompok siswa dalam menyelesaikan LKS dari pertemuan pertama, kedua dan ketiga di SDN Duyungan 1 mencapai $82 \%$ dan di SDN Sidoharjo 2 mencapai 
$88 \%$, persentase hasil pekerjaan LKS keduanya mencapai rata-rata $85 \%$, hal ini dapat dikatakan sangat baik. Siswa dapat menentukan keputusan, alasan dan menentukan nilai nasionalisme serta contohnya dengan sangat baik. Film dokumemter membatu siswa dalam memahami peristiwa perjuangan bangsa Indonesia dalam mempertahankan kemerdekaan. Film dokumenter sangat membantu siswa dalam memahami dilema untuk menentukan keputusan yang mereka anggap benar. Dengan melihat langsung adegan peristiwa pertempuran yang dialami bangsa Indonesia dari film dokumenter sangat membantu siswa dalam menentukan keputusan, alasan dan menentukan nilai nasionalisme serta contohnya di dalam Lembar Kerja Siswa.

Pembelajaran dengan model VCT berbantuan film dokumenter merupakan model VCT dengan metode percontohan yang akan mengantarkan siswa dalam memahami nilai nasionalisme melalui peristiwa dilema moral dari peristiwa dalam film dokumenter. Siswa akan menganalisis nilai-nilai nasionalisme melalui pengamatan film dokumenter mengenai peristiwa sejarah perjuangan Bangsa Indonesia dalam mempertahankan kemerdekaan, sehingga penanaman nilai nasionalisme kepada siswa akan dapat terlaksana dengan baik.
Teori belajar Bruner dalam Trianto (2007: 33) menjelaskan pentingnya pemahaman struktur kunci materi dari suatu ilmu yang dipelajari, perlunya belajar aktif dan nilai dari berpikir secara induksi dalam belajar. Terkait dengan teori ini, model Model VCT berbantuan film dokumenter menagrahkan bagaimana siswa menentukan keputusan dari dilema yang disajikan guru dan menentukan nilai-nilai nasionalisme berdasarkan film dokumenter yang telah disaksikan.

Adisusilo (2012:

menjelaskan VCT adalah pendekatan pendidikan nilai dimana peserta didik dilatih untuk menemukan, memilih, menganalisis, memutuskan, mengambil sikap sendiri nilai-nilai hidup yang diperjuangkannya. Dengan demikian, model VCT sangat sesuai untuk digunakan sebagai pendekatan dalam menanamkan nilai nasionalisme pada mata pelajaran IPS. Model VCT berbantuan film dokumenter menjabarkan beberapa komponenkomponen model. Model VCT berbantuan film dokumenter menjabarkan sintak yaitu langkahlangkah pelaksanaan kegiatan belajar mengajar, pengelolaan yang harus dilakukan guru saat proses belajar mengajar, sistem sosial yang harus dibangun, sistem pendukung yang dibutuhkan dalam penerapan model VCT berbantuan film dokumenter dan dampak instruksional dan 
pengiring yang ingin dicapai dengan VCT berbantuan film dokumenter.

Proses penerapan model VCT berbantuan film dokumenter memberi kebebasan siswa dalam menentukan keputusan yang mereka anggap benar dan menggali nilainilai nasionalisme berdasarkan film yang telah disaksikan. Siswa dapat dipertanggung jawabkan dengan baik berdasarkan apa yang mereka pilih. Hal ini sesuai dengan Frydaki (2008: 1497) yang menjelaskan bahwa peserta didik pada umumnya lebih senang diberi kebebasan untuk memilih nilai-nilai yang diyakini baik bagi dirinya, dan suatu paksaan dari pihak lain tidak akan ada gunanya.

Berdasarkan hasil penelitian ini terdapat relevansi dengan teoriteori yang dijadikan acuan penelitian. Fokus penelitian ini adalan penerapan model VCT berbantuan film dokumenter dalam menanamkan nilai nasionalisme pada siswa sekolah dasar. Hasil penelitian ini sesuai dengan Penelitian yang dilakukan oleh Nunuk Suyarni
(2013: 208) yang menyimpulkan bahwa model VCT efektif menginternalisasikan nilai karakter dalam pembelajaran sejarah. Selain itu Edgar Dale dalam Latuheru (1988) juga menjelaskan bahwa siswa lebih mudah dalam menganalisis nilai-nilai nasionalisme dengan melihat tayangan film dokumenter berdasarkan skenario dalam kegiatan belajar mengajar.

\section{Respons Siswa}

Setelah selesai penerapan model VCT berbantuan film dokumenter pada mata pelajaran IPS dari pertemuan pertama sampai pertemuan ke-3 baik di SDN Duyungan 1 dan di SDN Sidoharjo 2, selanjutnya peneliti meminta siswa untuk merespons proses pembelajaran dengan mengisi kuesioner angket yang telah disediakan. Hasil dari respons siswa di SDN Duyungan 1 dan di SDN Sidoharjo 2 terhadap penerapan model VCT berbantuan film dokumenter dapat dilihat pada Tabel 5.

Tabel 5 Respons Siswa Terhadap Penerapan Model VCT Berbantuan Film Dokumenter

\begin{tabular}{lcc}
\hline \multirow{2}{*}{ Data } & \multicolumn{2}{c}{ Respon Siswa } \\
\cline { 2 - 3 } & SDN Duyungan 1 & SDN Sidoharjo 2 \\
\hline Jumlah Siswa & 30 & 35 \\
\hline Rata-rata & 38,07 & 38,74 \\
\hline Rata-rata Skor maksimal & 40 & 40 \\
\hline Persentase & $95 \%$ & $97 \%$ \\
\hline Rata-rata Persentase & \multicolumn{2}{c}{$96 \%$} \\
\hline
\end{tabular}


Persentase respons siswa di SDN Duyungan 1 sebesar 95\% dan persentase siswa di SDN Sidoharjo 2 sebesar 97\%, sehingga keduanya mencapai rata-rata 96\%. Hal ini dapat dikatakan bahwa respons siswa terhadap penerapan model Value Clarification Technique (VCT) berbantuan film dokumenter pada mata pelajaran IPS adalah sangat baik. Siswa senang dengan pembelajaran, lebih mudah mempelajari materi IPS, menumbuhkan semangat belajar, dan lebih memahami nilai-nilai nasionalisme dengan penerapan model Value Clarification Technique (VCT) berbantuan film dokumenter.

\section{Hasil Belajar Siswa}

Sebelum dilaksanakan uji-t terlebih dahulu dilakukan uji normalitas. Uji normalitas kemampuan awal siswa (pretest) menggunakan uji KolmogorovSmirnov. Berdasarkan uji normalitas diperoleh p-value atau signifikansi dari nilai pretest adalah 0,340 . Hal ini dapat disimpulkan bahwa kemampuan awal (Pretest) antara siswa di SDN Duyungan 1 dan SDN Sidoharjo 2 berasal dari pupulasi yang berdistribusi normal karena $\mathrm{p}$ value atau signifikansi dari kelompok tersebut lebih besar dari $\alpha$ $=0,05$. Hasilanalisis data diperoleh nilai $\mathrm{t}$ hitung $(20,912)>\mathrm{T}$ tabel $(1,980)$ dengan p-value atau signifikansi $=0,000<\alpha(0,05)$. Berdasarkan hal ini dapat disimpulkan terdapat perbedaan sikap nasionalisme antara pretest dengan postest terhadap pelaksanaan model VCT berbantuan film dokumenter. Sehingga model VCT berbantuan film dokumenter efektif dalam menanamkan nilai nasionalisme kepada siswa.

Sebelum menganalisis perbedaan hasil belajar siswa dalakukan uju coba instrumen. Uji coba instrumen atau try out dilakukan untuk memperoleh validitas dan reliabilitas instrumen tes hasil belajar siswa. Soal tersebut tersebut diujicobakan kepada siswa sebanyak 30 siswa kelas V di SDN Singopadu 1. Berdasarkan uji validitas soal tes hasil belajar yang terdiri dari 30 soal pertanyaan pilihan ganda, terdapat 2 pertanyaan yang tidak valid. Hal tersebut dapat dilihat pada nilai $\mathrm{r}_{\text {hitung }}<\mathrm{r}_{\text {tabel }}(0,361)$. Nomor soal pertanyaan yang yang menunjukkan $r_{h i t u n g}<r_{\text {tabel }}(0,361)$ adalah pada soal nomor 11 dengan $\mathrm{r}_{\text {hitung }}=0,143$ dan soal nomor 27 dengan rhitung $=0,011$, dengan demikian soal hasil belajar tersebut tidak dipakai dalam penelitian. Sedangkan berdasarkan perhitungan menggunakan bantuan SPSS 20 diperoleh nilai reliabilitas uji coba tes hasil belajar mata pelajaran IPS siswa sebesar 0,982. Dengan demikian butir soal uji coba tes hasil belajar dinyatakan reliabel dengan tingkat reliabilitas sangat tinggi, sehingga layak digunakan sebagai instrumen penelitian. 
Penghitungan analisis aitem terdapat 1 butir soal uji coba tes hasil belajar pelajaran IPS yang tergolong sukar yaitu butir soal nomor 8; tergolong sedang yaitu nomor 1, 2, 3, $4,5,6,9,10,12,13,14,17,18,19$, $20,21,22,23,24,25,26,28,29$, dan 30 , tergolong mudah yaitu soal nomor 11, 15, 16, dan 27. Sedangkan berdasarkan daya beda (nilai D) perhitungan dari 30 soal tes hasil belajar didapatkan kesimpulan daya pembeda soal bahwa pada soal nomor $1,2,3,4,5,6,7,8,9,10,12$, $13,14,15,17,18,19,20,21,22,23$, $24,24,25,26,28,29,30$ memiliki indeks diskriminasi minimal $\mathrm{D} \geq$ 0,40 , dengan demikian soal tersebut dikatakan baik dan dipergunakan dan pada soal nomor 11, 16 dan 27 memiliki indeks diskriminasi $\mathrm{D} \leq$ 0,20 dengan demilkian soal tersebut dikatakan jelek, akan tetapi soal nomor 16 walaupun memiliki indeks diskriminasi $\mathrm{D} \leq 0,20$ memiliki kriteria valid dengan $\mathrm{r}_{\text {hitung }}=0,386$ jadi $r_{\text {hitung }}>$ rtabel $_{\text {tab }}(0,361)$. Berdasarkan perhitungan disimpulkan dari 30 soal diambil 28 soal tes hasil belajar yang dipakai dalam penelitian ini

Uji prasyarat analisis yaitu dengan uji normalitas dan uji homogenitas. Menguji normalitas kemampuan awal siswa (pretest) menggunakan uji KolmogorovSmirnovBerdasarkan uji normalitas tersebut diatas dapat disimpulkan bahwa p-value atau signifikansi dari nilai pretest adalah 0,079 . Hal ini dapat disimpulkan bahwa dari kelompok kontrol dan kelompok eksperimen berasal dari pupulasi yang berdistribusi normal karena $\mathrm{p}$ value atau signifikansi dari kelampok tersebut lebih besar dari $\alpha=0,05$

$$
\text { Sedangkan }
$$

homogenitas kemampuan awal siswa (pre-test) menggunakan uji Levene's test. Berdasarkan penghitungan harga Levene's test diperoleht-hitung $(1,020)<\mathrm{t}$ tabel $(1,980)$ dengan $\mathrm{p}$ value atau signifikansi $=0,310>\alpha$ $(0,05)$. Berdasarkan hal ini dapat disimpulkan kedua kelompok tersebut berasal dari varian yang sama, tidak ada perbedaan awal antara kelompok kontrol dengan kelompok eksperimen.

Adapun perbedaan rata-rata hasil belajar pretest dan post test antara kelas kontrol dengan kelas eksperimen adalah seperti pada Tabel 6.

Tabel 6 Analisis Hasil Belajar N-gain Kelas Eksperimen dan Kelas Kontrol

\begin{tabular}{ccccccc}
\hline \multirow{2}{*}{ Jenis Data } & \multicolumn{3}{c}{ Kelas Kontrol } & \multicolumn{3}{c}{ Kelas Eksperimen } \\
\cline { 2 - 7 } & Pretes & Postest & N-Gain & Pretes & Postest & N-Gain \\
\hline $\begin{array}{c}\text { Mean/ } \\
\text { Rata-rata }\end{array}$ & 37,58 & 79,42 & 0,7 & 39,85 & 88,72 & 0,8 \\
\hline
\end{tabular}

Berdasarkan nilai rata-rata tes bahwa setelah mengikuti hasil belajar siswa pada tabel terlihat pembelajaran IPS materi 
"Perjuangan Mempertahankan Kemerdekaan" nilai rata-rata pada kelas eksperimen sebesar 88,72 dan kelas kontrol sebesar 79,42. Peningkatan nilai kelas ekperimenlebih tinggi dibanding dengan kelas kontrol, terlihat dari nilai $\mathrm{N}$-gain antara kedua kelas. Ketentuan dari uji N-gain yaitu apabila $g \leq 0,3$ dapat dikatakan bahwa peningkatannya tergolong rendah, $0,3<\mathrm{g} \leq 0,7$ tergolong sedang dan $g>0,7$ tergolong tinggi. Berdasarkan ketentuan tersebut dinyatakan bahwa kelas kontrol peningkatanya tergolong sedang dengan $\mathrm{N}$-gain 0,7 dan kelas eksperimen peningkatanya tergolong tinggi dengan $\mathrm{N}$-gain 0,8 .

Setelah dilakukan uji normalitas dan homogenitas dan juga membandingkan hasil belajar siswa kelas eksperimen dengan kelas kontrol, maka untuk lebih menguatkan N-Gain maka dilakukan uji t. Uji t dilakukan untuk menguji perbedaan hasil belajar antara kelompok kontrol (siswa SDN Jetak 2) dan kelompok eksperimen (siswa SDN Duyungan 1 dan SDN Sidoharjo 2). Data yang digunakan untuk uji-t digunakan hasil belajar nilai post test siswa setelah dilaksanakan proses pembelajaran dengan model Value Clarification technique(VCT) berbantuan film dokumenter.

Berdasarkan analisis penghitungan melalui uji-t maka dapat diketahui $\mathrm{t}$ hitung $(5,788)>\mathrm{t}$ tabel $(1,980)$ dengan p-value atau signifikansi $=0,000<\alpha(0,05)$. Berdasarkan hal tersebut maka $\mathrm{H} 0$ ditolak dan $\mathrm{H} 1$ diterima, hal ini dapat disimpulkan kedua kelompok tersebut terdapat perbedaan antara kelompok kontrol tanpa menggunakan model Value Clarification technique(VCT) berbantuan film dokumenter dengan kelompok eksperimen yang menggunakan model Value Clarification technique(VCT) berbantuan film dokumenter.

Berdasarkan masing-masing skor rata-rata post test kelas kontrol di SDN Jetak 2 diperoleh skor ratarata 79 dan skor rata-rata post test kelas eksperimen 1 SDN Duyungan 1 diperoleh skor rata-rata 88 sedangkan skor rata-rata post test kelas eksperimen 2 SDN Sidoharjo 2 diperoleh skor rata-rata 89. Data ratarata post test yang diperoleh dapat dilihat pada Gambar 2 sebagai berikut. 


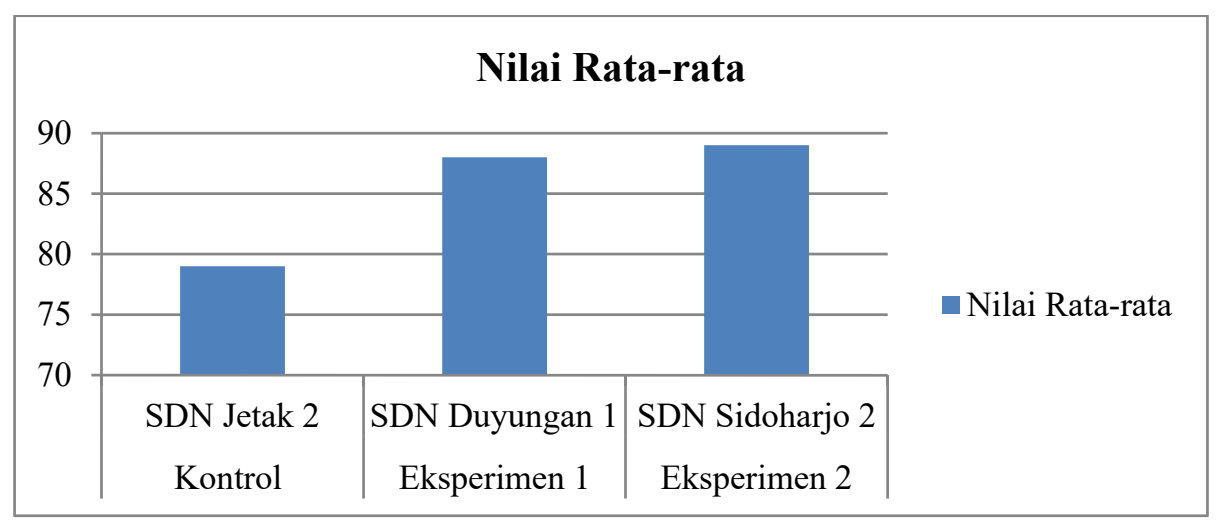

Gambar 2 Diagram skor rata-rata post test

Berdasarkan gambar di atas, dapat disimpulkan bahwa ada perbedaan skor rata-rata dari nilai post test antara kelompok yang menggunakan model Value Clarification technique(VCT) berbantuan film dokumenter dengan kelompok kontrol. Kelompok yang menggunakan model Value Clarification technique(VCT) berbantuan film dokumenter mendapatkan skor rata-rata lebih tinggi dibandingkan dengan kelompok yang menggunakan pembelajaran konvensional.

Jika dilihat dari nilai ketuntasan belajar dengan skor 75 maka penerapan model Value Clarification technique(VCT) berbantuan film dokumenter dari kelompok eksperimen mencapai 98\%. Hal ini dapat dilihat dari jumlah kelompok eksperimen 65 anak yang tidak mencapai nilai 75 sebanyak 1 anak. Sedangkan kelompok yang menggunakan model konvensional mencapai $84 \%$. Hal ini dapat dilihat dari jumlah kelompok kontrol sebanyak 31 anak yang tidak mencapai nilai 75 sebanyak 5 anak.

Sudjana (2000: 40) menjelaskan bahwa salah satu lingkungan belajar yang paling mempengeruhi hasil belajar di sekolah ialah kualitas pengajaran. Kualitas pengajaran adalah tinggi rendahnya atau efektif tidaknya proses belajar mengajaran. Penerapan model VCT berbantuan film dokumenter dalam penelitian ini selama proses pembelajaran diperoleh data tentang pelaksaan guru dalam kegiatan belajar mengajar, sikap siswa, hasil LKS, respon siswa, hasil skala sikap nasionalisme dan hasil belajar. Berdasarkan data yang diperoleh dari penerapan nilai nasionalisme dengan model VCT berbantuan film dokumenter dalam menanamkan nilai nasionalisme secara kaseluruhan dikatakan sangat baik. Hal ini sesuai dengan penelitian yang dilakukan oleh Herniawati (2011: 90) yang menyimpulkan bahwa penanaman nilai-nilai nasionalisme 
siswa melalui pembelajaran dengan menggunakan metode VCT semakin baik.

Bardasarkan analisis ketercapaian indikator-indikator penanaman nilai nasionalisme dalam Lembar Kerja Siswa (LKS), hasil kerja kelompok siswa dalam menyelesaikan LKS dari pertemuan pertama, kedua dan ketiga dapat dikatakan sangat baik. Siswa dapat menentukan keputusan, alasan dan menentukan nilai nasionalisme dari beberapa alternatif pilihan serta memberikan contohnya dengan sangat baik,semuanya dilakukan berdasarkan apa yang diyakini siswa sebagai sesuatu yang dianggap benar. Hal ini sesuai dengan teori konstruktifisme yang dijelaskan Aqib (2011: 53) bahwa orang menyusun atau membangun pemahaman mereka dari pengalaman-pengalaman baru berdasarkan pengetahuan awal dan kepercayaan mereka. Siswa dapat mengkontruksi sendiri pengetahuan yang harus dikuasai dengan menyaksikan film dokumenter mengenai kisah perjuangan bangsa Indonesia dalam mempertahankan kemerdekaan.

Hasil belajar dapat berhasil dengan baik apabila didukung dengan proses pembelajaran yang baik. Hal ini sesuai dengan Sudjana (2000: 40) menjelaskan bahwa salah satu lingkungan belajar yang paling mempengeruhi hasil belajar di sekolah ialah kualitas pengajaran. Nasution (2002: 45) menjelaskan bahwa hasil belajar adalah kemampuan anak didik berdasarkan hasil dari pengalaman atau pelajaran setelah mengikuti program belajar secara periodik. Hasil belajar siswa dalam penelitian ini diperoleh setelah penerapan model Value Clarification technique(VCT) berbantuan film dokumenter. Hasil belajar dengan menggunakan model VCT berbantuan film dokumenter memiliki kemampuan yang lebih baik dari hasil belajar pada kelas kontrol dengan pembelajaran konvensional. Edgar Dale dalam Latuheru (1988) yang menjelaskan bahwa orang akan memperoleh pengalaman belajar dari kenyataan dalam kehidupannya. Pengalaman belajar seseorang lebih besar diperoleh melalui indera penglihatan (mata), dibandingkandiperolah melalui indera pendengaran (telinga). Berdasarkan uraian di atas maka dapat ditarik kesimpulan bahwa terdapat perbedaan hasil belajar antara penerapan model pembelajaran Value Clarification technique(VCT)berbantuan film dokumenter dengan pembelajaran konvensional pada mata pelajaran IPS.

\section{Penutup}

Model Value Clarification technique (VCT) berbantuan film dokumenter merupakan teknik klarifikasi nilai nasionalisme dengan metode percontohan film dokumenter yang terdiri dari 7 
tahapan yaitu pemberian stimulus film dokumenter, menyajikan dilema dari film dokumenter, mendalami dilema, dialog terpimpin, fase menentukan argumen dan klarifikasi nilai, fase pembuktian dan argumen dan fase penyimpulan. Perangkat pembelajaran yang diperlukan meliputi silabus, RPP, bahan ajar, lembar kerja siswa, tes hasil belajar siswa, dan film dokumenter.

Proses penerapan model Value Clarification technique (VCT) berbantuan film dokumenter dalam menanamkan nilai nasionalisme diawali dengan kegiatan pendahuluan dilanjutkan dengan menyaksikan film dokumenter, melalui film dokumenter disajikan dilema dan pendalaman dilema, kemudian melaksanakan diskusi kelompok dan hasilnya dipresentasikan dengan mengklarifikasi nilai nasionalisme, selanjutnya membuktikan keputusan yang telah diambil, kemudian menyimpukan dengan memberi contoh bagaimana cara mengimplementasikan nilai-nilai nasionalisme dalam kehidupan sehari-hari dan diakhiri dengan penutup. Penerapan modelValue Clarification technique (VCT) berbantuan film dokumenter dalam menanamkan nilai nasionalisme dapat berjalan dengan efektif. Hal ini dapat dilihat berdasarkan analisis hasil observasi guru, sikap siswa dalam kegiatan belajar mengajar, analisis Lembar Kerja Siswa, dan respon siswa selain itu dengan uji $\mathrm{t}$ dapat disimpulkan bahwaterdapat perbedaan sikap nasionalisme antara pretest dengan postest terhadap penerapan model VCT berbantuan film dokumenter.

Terdapat perbedaan hasil belajar antara penerapan model pembelajaran Value Clarification technique(VCT) berbantuan film dokumenter dengan pembelajaran konvensional pada mata pelajaran IPSsiswa kelas V SD Negeri DABIN 1 di Kecamatan Sidoharjo Kabupaten Sragen. Hasil belajar siswa pada kelas eksperimen yang menggunakan model Value Clarification Technique (VCT) berbantuan film dokumenter lebih baik dari kelas kontrol yang menggunakan pembelajaran konvensional.

\section{Daftar Pustaka}

Adisusilo, S. 2012. Pembelajaran Nilai-Karakter: Konstruktivisme dan VCT Sebagai Inovasi Pendekatan Pembelajaran Efektif. Jakarta: PT. Rajagrafindo Persada.

Aqik, Z dan Sujak. 2011. Panduan \& Aplikasi Pendidikan Karakter. Bandung: Yrama Widya.

Djahiri, K.A, 1985. Strategi Pengajaran Afektif-Nilai-Moral VCT dan Games dalam VCT. Bandung:PMPKN FPIPS IKIP Bandung.

Frydaki, E., Mamoura, M. 2008. Exploring Teachers Value 
Orientation In Literature and History Secondary Classrooms, In Teaching and Education. An International Jurnal of Research and Studies. London U.K.: Elsevier Ltd. 10 Januari 2008 .

Herniawati. 2011. Menanamkan Nilai NasionalismeMelalui Model Pembelajaran VCT Pada $\begin{array}{llll}\text { SiswaKelas } & \text { VI } & \text { SDN } 88\end{array}$ PERUMNAS. Jurnal Kependidikan Triadik, (Online), (volume 14 No. 1. 2011) (http://www.google.co.id/url?q= http://repository.unib.ac.id), diakses 07 Februari 2013.

Latuheru J.D. 1988. Media Pembelajaran (Dalam Proses Belajar Mengajar Masa Kini). Jakarta: Dekdikbud Dirijen Dikti Proyek Pengambangan Lembaga Pendidikan Tenaga Kependidikan.

Nasution, S. 2002. Didaktik Asasasas Mengajar. Bandung: Jemmers.
Sudjana, N. 2000. Dasar-Dasar Proses Belajar Mengajar. Bandung: Sinar Baru Algesindo.

Suprayogi, dkk. 2011. Pendidikan Ilmu Pengetahuan Sosial. Semarang: Widya Karya.

Suryani, N. 2013. Pengembangan Model Internalisasi Nilai Karakter Dalam Pembelajaran Sejarah Melalui Model Value Clarification Technique. Jeural Paramita Vol. 23 No. 2 - Juli 2013. (ISSN: 0854-0039), Hlm. 208-219.

Trianto. 2007. Model Pembelajaran Terpadu Teori dan Praktek.Jakarta: Prestasi Pustaka Publiser.

Undang undang Republik Indonesia Nomor 20 Tahun 2003 tentang Sistem Pendidikan Nasional. 2003. Jakarta: Depdiknas. 